\title{
67. Bir çeviri türü olarak sosyal bilimler çevirisi özellikleri, çeviri olguları ve mesleki yeterlilikleri
}

\section{Lale ÖZCAN ${ }^{1}$}

\begin{abstract}
APA: Özcan, L. (2021). Bir çeviri türü olarak sosyal bilimler çevirisi özellikleri, çeviri olguları ve mesleki yeterlilikleri. RumeliDE Dil ve Edebiyat Araştırmaları Dergisi, (22), 1052-1066. DOI: 10.29000/rumelide.897354.
\end{abstract}

\section{$\ddot{O} \mathbf{z}$}

Sosyal bilimler alanındaki metinler yoğun bilgi içeren, terim ve kavram anlamında özel alan çevirmenliği kadar uzmanlık ve yetkinlik isteyen, biçemsel yönden yazın eserleriyle karşılaştırılabilecek ölçüde yazarlarının izini ve biçemini belirten özel metinler olarak karşımıza çıkmaktadır. Sosyal bilimler içerdikleri bilgi ve terim yüküyle teknik çeviri alanının pek çok gereklerine hitap ettikleri gibi yazınsal biçemleri, dilleri ve hitap ettikleri kitlelerin çeşitliğ açısından da yazınsal çeviri türüne özgü bazı hasletlere de sahip olmayı gerektirirler. Bunlara ek olarak sosyal bilim metinleri, özel alanlarda üretilen metinler olarak genel kitap çevirilerinden de nitelik olarak belirgin farklılık göstermektedirler. Bu nedenlerle, sosyal bilimlerin çevirilerini belirli bir çeviri türüne yerleştirebilmek mümkün gözükmediğinden, bu çevirileri, kendine özgü bir çeviri türü olarak tanımlayabiliriz. Bu nedenle, bu çeviri türüne özgü çeviri olgularını, bu olguların getirdiği güçlükleri, sorunları, bunların çözülebilmesini sağlayacak çözüm önerilerini belirlemek, bu çeviri türünün mesleki yeterlilik çerçevesini çizmeye çalışmak makalemizin kapsamını oluşturmaktadır. Makalemizde ilk olarak sosyal bilimler çevirisi alanının tanımını, bu konuda daha önce çalışmış çeviri kuramcılarının görüş ve önerilerine değinerek yapmaya çalışacağız. Ardından alanda çalışan uzman çevirmenlerin deneyimlerinin ışığında sosyal bilimlerin çevirilerinin özellikleri çeşitli örnekler üzerinden incelenecektir. Sonrasında özellikle sosyal bilimler çevirisi alanında önemli çalışmalara imza atan Sündüz Öztürk Kasar'ın alanla ilgili görüş ve açılımlarına başvurarak bu çeviri türü özelinde karşılaşılan kimi zorlukların aşılmassı yönünde kullanılabilecek çeviri yöntemlerine dair öneriler getirilecektir. Son olarak bu çeviri türünde çalışan ya da çalışacak olan çevirmenlerin ne tür mesleki yeterliliklere sahip olmaları gerektiği konusunda bir taslak çizilmeye çalışılacaktır. Çalışmamızın sosyal bilimlerin çevirisi türünde farkındalık yaratması, bu türe özgü çeviri sorunsallarının daha fazla tartışılmasına bir nebze katkı sağlaması ise amaçlanan sonucumuz olacaktır.

Anahtar kelimeler: Sosyal bilimler çevirisi, sosyal bilimlerde çeviri özellikleri ve olguları, sosyal bilimlerde çeviri zorlukları ve yöntemleri, mesleki yeterlilikler

\section{Social sciences translations as a category of translation: characteristics, translation facts and professional proficiencies}

\begin{abstract}
The articles in the field of social sciences appear as special texts that contain intense knowledge, expertise and competence as much as special field translation in terms of terms and concepts, and the style of their authors that can be compared with literary works in a stylistic way. Social science
\end{abstract}

Doç. Dr., Yıldız Teknik Üniversitesi, Fen Edebiyat Fakültesi, Batı Dilleri ve Edebiyatları Bölümü, Fransızca Mütercim ve Tercümanlık ABD (İstanbul, Türkiye), ozcanlale@hotmail.com, ORCID ID: oooo-0oo2-7565-4565 [Araştırma makalesi, Makale kayıt tarihi: 17.12.2020-kabul tarihi: 20.03.2021; DOI: 10.29000/rumelide.897354]

Adres $\mid$ Address

RumeliDE Dil ve Edebiyat Araştırmaları Dergisi $\quad$ RumeliDE Journal of Language and Literature Studies Osmanağa Mahallesi, Mürver Çiçeği Sokak, No:14/8 Osmanağa Mahallesi, Mürver Çiçeği Sokak, No:14/8

Kadıköy - İSTANBUL / TÜRKIYE 34714 Kadıköy - ISTANBUL / TURKEY 34714 e-posta: editor@rumelide.com

e-mail: editor@rumelide.com

tel: +90 $5057958124,+902167730616$ phone: +90 505 7958124, +90 2167730616 
translations also fulfill many requirements of the technical translation with their information and term load. In terms of their literary styles, languages and the variety of audiences; they also bear some characteristics of literary translation. As done in special fields, they differ from general book translations. Due to these reasons and since it does not seem possible to place the translations of social sciences in a specific type of translation, we can define these translations as a unique category of translation. Therefore, the scope of our article is to determine the translation facts specific to this translation type, the difficulties and problems caused by these facts, and the solution proposals that will enable them to be solved, and to try to draw the framework of professional competence of this translation type. In our article, we will firstly try to define the field of social sciences translation by referring to the views and suggestions of translation theorists who have worked on this subject before. Then, in the light of the experiences of expert translators working in the field, the features of the translations of social sciences will be examined through various examples. Afterwards, suggestions will be made on translation methods that can be used to overcome some difficulties encountered in this translation type by referring to the views and expansions of Sündüz Öztürk Kasar, who has made important works in the field of social sciences translation. Our aim will raise awareness of social science translation and to contribute to the further discussion of translation problems in this field.

Keywords: Social science translation, the translation facts specific to social science translations, translation difficulties and methods in social sciences, professionnal deficiencies

\section{Giriş}

Sosyal bilimler çevirisi olarak adlandırabileceğimiz çeviri alanını, kendine özgü bir çeviri türü olarak tanımlamak, bu türün özelliklerini belirlemek, karşılaşılabilecek kimi zorlukları ele almak ve bu zorlukları aşmaya yönelik önerilerde bulunmak ve bir sosyal bilimler çevirmeninde olması gerektiğini düşündüğümüz mesleki yeterlikleri tanımlamak çalışmamızın amacını oluşturmaktadır. Makalemizde ilk olarak sosyal bilimler çevirisi alanının tanımı, bu konuda daha önce çalışmış çeviri kuramcılarının görüş ve önerilerine değinilerek yapılmaya çalışlacaktır. Ardından bu çeviri türünün özellikleri, bu alana dair kimi çeviri zorlukları ve sorunsalları alandan seçilen örnekler üzerinden incelenecektir. Konunun uzmanlarının özellikle de bu alanda önemli çalışmalara imza atan Sündüz Öztürk Kasar’ın görüş ve açılımlarına başvurarak bu zorlukların ve sorunsalların aşılması yönünde kullanılabilecek çeviri yöntemleri ele alınacak ve öneriler getirilmeye çalışlacaktır. Son olarak bu çeviri türünde çalışan ya da çalışacak olan çevirmenlerin ne tür mesleki yeterliliklere sahip olmaları gerektiği konusunda büyük oranda Sündüz Öztürk Kasar'ın alandaki çalışmalarında yapmış olduğu saptamalardan yola çıkılarak bir çerçeve çizilmeye çalışılacaktır. Çalışmamızın sosyal bilimlerin çevirisi türünde farkındalık yaratması, bu türe özgü çeviri sorunsallarının daha fazla tartışılmasına bir nebze katkı sağlaması ise amaçlanan sonucumuz olacaktır.

Sosyal bilimler çevirisiyle ilgili olarak öncelikle bu alanın sınırsızlı̆̆ına dikkat çekmek istiyoruz. "Sınırsızlık”tan kastımız "iki yönlü”: Bu alanın sınırsızlığı, çevirebileceğiniz konu ve bilimdalının çeşitliğini ve enginliğini işaret ettiği gibi bir sınırı ya da bir sınıfı olmaması durumunu da işaret etmektedir. Sosyal bilimlerin çevirisi ne yazınsal ne teknik ne de özel alan çevirisi kapsamına giren "hepsinden biraz" deyişine oturan bir alandır. Bu bağlamda, sosyal bilimlerin çevirisi konusunda çeviribilim alanında da çok fazla çalışma ve araştırma bulunmadığı da söylenebilir. Sosyal bilimlerin çevirisi olarak çok satan bir çevirinin ya da yıllar sonra Türkçe'ye taşınabilmiş önemli bir bilim kitabının çevirisinin gündemimizi meşgul ettiği durumların çok fazla olmadığı da açıktır sanırız. Sosyal

\footnotetext{
\begin{tabular}{r|l} 
Adres & Address \\
RumeliDE Dil ve Edebiyat Araştırmaları Dergisi & RumeliDE Journal of Language and Literature Studies
\end{tabular} Osmanağa Mahallesi, Mürver Çiçeği Sokak, No:14/8 Osmanağa Mahallesi, Mürver Çiçeği Sokak, No:14/8 Kadıköy - İSTANBUL / TÜRKIYE 34714 Kadıköy - ISTANBUL / TURKEY 34714 e-posta: editor@rumelide.com e-mail: editor@rumelide.com, tel: +90 505 7958124, +90 2167730616 phone: +90 505 7958124, +90 2167730616
} 
Social sciences translations as a category of translation: characteristics, translation facts and professional proficiencies / L. Özcan (pp. 1052-1066)

bilimlerin çevirileri, genelde, kitap çevirisi denilince akla ilk gelen yazınsal çevirinin ötesinde, adı çok geçmeyen bir alt tür olarak algılanmaktadır. Teknik çeviri sınıflamasında öncelikle, safi terim, yöntem ve uygulama içeren "teknik, teknolojik" metinler akla gelmektedir.

Sosyal bilimlerin çevirilerini, çeviri sektörü açısından arz/talep bağlamında değerlendirdiğimizde de sosyal bilimlerin çevirisi, fazla tiraj yapmayan, çok satmayan, çevirmesi uzun süren ve yoğun emek gerektiren, çok az sayıda basımı olan ve yayınevlerinin genel radarının bir hayli uzağında kalan bir çeviri türü olarak karşımıza çıkmaktadır.

Bu noktada uzun yıllardır sosyal bilim kitaplarının çevirmenliğini yapan, deneyimli çevirmen Işık Ergüden'in "Yaşadığımız hayatlar, tam da bu hayatları ele alan sosyal bilim metinlerini alımlamaya ne ölçüde imkan tanıyor" (2015) saptamasından yola çıkarak şu soru sorulabilmektedir: "Ve çeviri piyasası bu metinlerin çevirisine ne ölçüde emek veriyor, ya da emek verilmesine imkan tanıyor?" Çünkü kitap çevirmeni olarak tanımlanan meslek erbaplarının yani "kafa emekçilerinin" (Ergüden, 2015) kimi sektörel sorunları olduğu açıktır. Tüm kitap çevirmenleri için geçerli olmakla birlikte sosyal bilimler çevirmenleri için de bu sorunları yasal çerçeveden yoksunluk, emek ve emeğin bedeli arasındaki dengesizlik, görünürlük, tanınırlık ve liyakat sorunları olarak özetleyebiliriz.

\title{
2. Sosyal bilimlerin çevirilerinin önemi ve kapsamı
}

Sosyal bilimlerin çevirisi, diğer tüm çeviri türleri gibi kültürler ve elbette bilimsel çevreler arasında bilgi ve görüş alışverişini sağlamak başta olmak üzere pek çok açıdan büyük önem arz etmektedir. Sosyal bilimler alanında çevirinin önemine öncelikle Goethe'nin 1827'de çevirmeni Thomas Carlyle'e gönderdiği mektuptaki sözleriyle değinilebilir:

\begin{abstract}
"Ben çevirmenleri, evrensel düşünce alışverişinin aktörleri, aracıları ve bu büyük çaplı ticaretin ilerlemesini kendilerine vazife bilmiş neferler olarak görüyorum ve böyle görülmesi gerektiğini düşünüyorum”2 (aktaran Berrichi, 2012:17).
\end{abstract}

Düşünce aktarımı açısından, Gisèle Sapiro'nun da ifade ettiği üzere özellikle 19. yüzyllından itibaren çeviri en önemli dolaşım araçlarından biri olmuş, ulusal kimliklerin kültürel oluşum süreci olarak uluslararasılaştırma görüngüsünü oluşturmuştur (Sapiro, 2012:6). Bu minvalde Sündüz Öztürk Kasar’a göre, sosyal bilim çevirisi öncelikle siyasal ve toplumsal düşüncenin tüm dünyada yayılmasının ve dolaşımının en önemli göstergelerinden biridir (2010:6). Gerçekten de sosyal bilimlerin çevirileri bilim tarihinde çok önemli bir rol oynamıştır. Dolayısıyla bu alanda yapılacak bilimsel araştırmalar aynı zamanda bilim tarihine de katkı sağlayacaktır (Schögler, 2017:37).

Kültür ve bilgi aktarımı açısından önemi tartışılmaz sosyal bilimler çevirisinin hangi çeviri türüne dahil edilebileceği konusunda, Berrin Aksoy, sosyal bilimlerin çevirilerinin çeviri türleri açısından yazınsal çeviri ve teknik çeviri arasında bir ara konumda olduğunu belirtir ve bu metinlerin Katherina Reiss'ın üç işlev alanına girdiğini ifade eder: Bilgisel, anlatımcı ve işlevsel (1999:21). Yine Aksoy'un tanımıyla "Sosyal bilim metinleri çevirisinin, yazın çevirisinin tüm güçlüklerini ve teknik çevirinin tüm tekniklerini içerdiğini söyleyebiliriz.» (1999: 21). Aksoy, ayrıca sosyal bilimlerin çevirisinde Skopos kuramını "işlevsel" bir kuram olarak tanımlar. Bunun nedeni olarak da bu çeviri türünde, varış metninin, diğer çeviri türlerine göre çok farklı bir önem arz etmesini gösterir (1999:22). Bu nedenle Aksoy, sosyal bilim metinlerini çeviren bir çevirmenin, çevirinin işlevini ve amacını net bir biçimde en

Makale içinde yer alan yabancı dillerden yapılan alıntıların çevirisi aksi belirtilmedikçe makalenin yazarı tarafından gerçekleştirilmiştir.

RumeliDE Dil ve Edebiyat Araştırmaları Dergisi Osmanağa Mahallesi, Mürver Ciçeği Sokak, No:14/8 Kadıköy - ISTANBUL / TÜRKIYE 34714 e-posta: editor@rumelide.com tel: +90 $5057958124,+902167730616$
Address

RumeliDE Journal of Language and Literature Studies

Osmanağa Mahallesi, Mürver Çiçeği Sokak, No:14/8

Kadıköy - ISTANBUL / TURKEY 34714

e-mail: editor@rumelide.com,

phone: +90 505 7958124, +90 2167730616 
başından ortaya koyması gerektiğinin altını çizer (1999:26). Zira ortaya çıacak güçlüklere bulunacak çözümler bu başlangıçtaki amaç ve işlev çerçevesi içinde çözümlenecektir.

Dolayısıyla sosyal bilimler alanında çeviri, öncelikle bilişsel bir edimdir sadece iletişim edimi olarak görülemez, ancak aynı zamanda bir yazım edimidir, tıpkı kurgu metinler gibi. Aksoy gibi Berrichi de sosyal bilimlerin çevirisinin en önemli özelliği olarak bu çevirilerin alımlanma süreçlerinin özgünlügünü dile getirir: Bu alımlama, her ulusa özgü tasavvurlarla, unsurlarla, aktörlerle ve bağlamla çok yakından ilintilidir (Berrichi, 2012: 18).

Bu noktada, sosyal bilim çevirilerinin ait oldukları dil düzeyi devreye girmektedir. Öztürk Kasar bu konuyla ilgili olarak kuram dilinden söz eder:

\begin{abstract}
«Aslında söz konusu olan bir üstdildir. Bu üstdilin kendi ifadeleri, deyişleri, ulaçlar ve biçemi bulunur. Bu tür kuramsal dille örülen kuram metni de kendine özgü özellikleri olan bir metindir zira bu tür bir metnin bağlamı yeni kavramların oluşturulduğu, yeni terimlerin adlandırıldığı hatta yeni bilimdallarının doğuşunu getiren bir bağlamdır» (2018a: 72).
\end{abstract}

Aynı kurgusal metinlerde olduğu gibi sosyal bilim metinlerinin yazarlarının da (biliminsanları, uzmanlar, akademisyenler vb.) kendilerine özgü bir dili, ifade tarzı vardır ve bunu metinlerine yansitırlar. Jean René Ladmiral, sosyal bilimlerin çevirisinde çevirmenin "sözü" çevirdiğini ısrarla ifade etmiş ve yapmış olduğu Kant çevirilerinde, "kendisini Fransızca ifade eden bir Kant” yarattığını belirtmiştir (aktaran Öztürk Kasar, 2010: 3).

Sosyal bilimlerde gerçekleştirilen çevirilerin yukarıda değinmeye çalıştığımız özellikleri düşünülünce bu çevirilerin, farklı bir çeviri türü oluşturduğu ve gerek çeviribilim alanına gerek küresel çapta düşünce, bilim ve bilgi dolaşımına büyük katkı sağladıkları açıtır. Bu noktadan hareketle, bu çevirilerin basım yayın sektöründeki yerlerinin, bu sektördeki aktarım ve dolaşım koşullarının ve süreçlerinin tanımlanması önem taşımaktadır.

\title{
3. Sosyal bilimlerin çevirilerinde dolaşım ve alımlanma koşulları
}

Pierre Bourdieu, "Les conditions sociales de la circulation internationale des idées" başlıklı makalesinde sosyal bilimler alanında gerçekleştirilen yayınların aktarım ve dolaşım koşullarını incelemiştir (2002). Bourdieu'nün incelemesinde yapmış olduğu önemli bir saptama, ulusal basım yayın koşullarının sosyal bilimlerde gerçekleştirilen yayınların alımlanma koşullarını önemli oranda etkilediğidir. Bu doğrultuda, «Ne çeviriliyor? Ne yayımlanıyor? Kim çeviriyor? Kim yayımlıyor?» sorularının cevapları sosyal bilimlerin alımlanmasında büyük bir etkendir (Bourdieu, 2002: 4). Bir sosyal bilim eserine yazılan önsöz ve bu önsözün yazarı bile ilgili eserin varış kültüründeki alımlanma sürecinde belirleyici bir rol oynar. Bir eserin çeviri için seçilmesinin nedenleri de arka planda eserin alımlanmasını belirleyen olgulardır. Bourdieu bunları, karşılıklı çıkar ilişkileri, hayranlık ilişkileri, kurumsal fayda ve çlkar faktörü olarak sıralar (2002:5).

Bu alanın bir diğer uzmanı olan Sapiro'dan yola çıkarak sosyal bilimlerin metinlerinin üretimiyle ilgili özel durumların da bu metinlerin çevirilerini doğrudan ilgilendirdiğini söyleyebiliriz. Bu alandaki İngilizce hakimiyeti bu açıdan önemli bir faktördür. Sapiro’ya göre, bu dilin hakimiyeti uzmanlar arasındaki düşünce ve bilgi alışverişine ciddi kısıtlamalar getirmektedir. Sapiro, bu duruma nicel bir gösterge olarak, 1990'dan itibaren Avrupa içi ülkelerin araştırmacılarının ortak makalelerinde ciddi bir artış olduğunu ancak Amerikalı ve Avrupalı araştırmacıların ortak makale oranının çok daha yüksek olduğunu belirtir (2012:9). Ayrıca araştırmacıların üzerindeki İngilizce yayın yapma baskısının başka

Adres Address

RumeliDE Dil ve Edebiyat Araştırmalar Dergisi $\quad$ RumeliDE Journal of Language and Literature Studies Osmanağa Mahallesi, Mürver Çiçeği Sokak, No:14/8 Osmanağa Mahallesi, Mürver Çiçeği Sokak, No:14/8

Kadıköy - İSTANBUL / TÜRKIYE 34714 Kadıköy - ISTANBUL / TURKEY 34714 e-posta: editor@rumelide.com

tel: +90 505 7958124, +90 2167730616 phone: +90 505 7958124, +90 2167730616 
Social sciences translations as a category of translation: characteristics, translation facts and professional proficiencies / L. Özcan (pp. 1052-1066)

dillerden çeviri talebini ciddi oranda etkilediği Sapiro'nun bir diğer savıdır. Ancak bu araştırmacılar için İngilizce yayın yapmak ortak dolaşıma açılmak için yeterli gelmemektedir. Sapiro bu durumu «makalenin formatı, savlama yöntemi ve biçemi ülkeden ülkeye hatta bilimdalından bilimdalına önemli değişkenlik göstermektedir ve bir makalenin kabulü bu şartlarda çok zor olmaktadır.» biçiminde açıklamaktadır (2012:10). Bu koşullar, bilgi ve düşünce aktarımı ve dolaşımı alanından çevirinin dışlanması sonucunu getirmektedir. Bu noktada Sapiro, sosyal bilimlerde çevirinin düşünce ve ifade özgürlüğü açısından taşıdığı yaşamsal önemin altını çizmektedir:

“(...) çeviri gerçek bir zenginliktir zira göreceliliği desteklemekte ve düşünce kategorilerini kendi bağlamlarından çıkartmakta, ortak sağduyuyu güçlendirmektedir böylece düşüncelerin standartlaştırılmasına karşın bir bariyer görevi görmektedir” (2012:10).

Sonuç olarak sosyal bilimlerin çevirileri özel bir çeviri türdür. Dolayısıyla, bu çeviri türünün oluşturduğu uygulama alanına özgü zorlukların, sorunsalların ve bu zorlukların üstesinden gelmek için başvurulabilecek çeviri yöntemlerinin tanımlanmasının önem taşıdığını düşünmekteyiz.

\section{Sosyal bilimlerin çevirilerinin özellikleri}

\subsection{Sosyal bilimlerin çevirilerinde kavram ve terim aktarımı}

Sosyal bilimlerin çevirisi, düşünsel birikimin çok fazla olmasını gerektiren bir çeviri türüdür (Ergüden, 2015). Özgün metinlerde kullanılan kavramlar çoğu zaman aynı soyutluk düzeyinde başka kavramlara, başka disiplinlere gönderme yaparlar, gösteren-gösterilen ilişkisinde tamamen farklı bir dil düzeyi kurulur. Ergüden, bu zorluğu, yazınsal eser çevirilerindeki aynı düzlemdeki güçlükle şu biçimde kıyaslamaktadır:

"Edebiyat metinleri, genellikle gerçek hayata paralel kurmaca bir hayata gönderme yaptıklarından çeviri sürecinde metnin içine girebilen çevirmen, iki dile ve kültüre hakimse, başka bir bilgi düzeyine ihtiyaç duymadan ... metni çözebilir" (2015).

Buna karşın sosyal bilimlerde çeviri yapan bir çevirmen, ilgili alanının ve eserin uzandı̆̆ı her alana ve her esere dair pek çok yan okuma yapması gerektiğinin bilincinde olmalıdır. Bu duruma bir örnek tarafımızdan gerçekleştirilen 2009 yılında yayımlanan bir çeviri eserden verilebilir. Michel de Certeau'nun L’invention du quotidien eserinin Türkçe çevirisi Gündelik Yaşamın Keşfi başlığıyla 2009 ylında Dost Kitabevi’nden yayımlanmıştır. Bu eseri çevirirken, çevirmenin gerçekleştirmesi gereken araştırma, yan okuma, kuramsal ve yazınsal okuma boyutunu yine Luce Giard'ın eser için kaleme aldığı Önsöz'den alıntılanan şu bölümler açıkça ifade etmektedir kanısındayız:

«(...) Antigon, Uyuyan Güzel, Külkedisi, Daidalos, İkaros, Oidipos, Robinson ve Cuma, Scapin, Ulrich, Dora ve Küçük Hans, Emile, Figaro, Don Juan, Leydi Macbeth ve daha pek çok kahraman bu sayfaları süslemektedir» (Certeau, 2009: 35)

«Certeau, sözlerle oynamasını çok iyi biliyor ve özel diller arasında rahatlıkla geçiş yapabiliyor. Kimi zaman tıp ve toplum tarihçisi oluyor, kimi zaman tanrıbilimci kimi zaman da Freud'un ya da Foucault'nun ardılı, nicel bilimcisi ve psikanalist olarak karşımıza çıkıyor» (Certeau, 2009: 11)

Sosyal bilimlerin çevirisinin en önemli aşamalarından biri de alana ait terim çalışmasıdır. Çevirmenin terim bilinci ve edincine sahip olması, terim tanımlama, sınıflama, araştırma ve oluşturma aşamalarını gerçekleştirebilmesi ve gerçekleştirmek zorunda olduğunu bilmesi gerekir. Bu çerçevede, kendisi de çok yetkin bir sosyal bilimler çevirmeni olan Öztürk Kasar bir terim sınıflama şeması sunmaktadır (2015). Bu şemaya göre sosyal bilimler çevirmeni karşısına çıan terimleri belirli bir sınfflama dahilinde ele alabilir:

RumeliDE Dil ve Edebiyat Araşttrmaları Dergisi Osmanağa Mahallesi, Mürver Ciçeği Sokak, No:14/8 Kadıköy - İSTANBUL / TÜRKIYE 34714 e-posta: editor@rumelide.com tel: +90 $5057958124,+902167730616$
Address

RumeliDE Journal of Language and Literature Studies

Osmanağa Mahallesi, Mürver Çiçeği Sokak, No:14/8

Kadıköy - ISTANBUL / TURKEY 34714

e-mail: editor@rumelide.com,

phone: +90 505 7958124, +90 2167730616 
- Gündelik dilde var olan ilgili alanda terim niteliği kazanan sözlükbirimler;

- Dilde başka bir bilimdalında terim olarak var olan ve sözkonusu bilim alanına geçirilmiş ödünç terimler;

- Karşılı̆̆ bulunmayan yeni üretilen terimler;

- Zamanla ilgili bilim alanının da sınırlarını aşarak bir kavram olarak gündelik dile oturan ve "sözbirim" niteliği kazanan sözlükbirimler (2015: 62-63).

Dolayısıyla sosyal bilimlerin çevirilerinin elbette en önemli meydan okumalarından biri de özgün eserde geçen terimleri erek dilde karşılamaktır. Kasar'ın Algirdas Jülien Greimas'ın La semantique structurale eserinin çevirisi için araştırılması gereken terimleri belirlediği makalesinde dile getirdiği oran bu tür bir çeviriye kalkışan çevirmenin yapmak zorunda olduğu terim araştırmasına çarpıcı bir örnek teşkil etmektedir. Öztürk Kasar, Greimas'ın La semantique structurale eserinin çevrilmesi için 555 terimin araştırılması gerektiğinden yola çıkarak yapmış olduğu kaynakça araştırması sonucunda bu terimlerin sadece \% 51,8'nin Türkçe'de oturmuş bir karşlığının olmadığı saptamasında bulunmuştur (2018a:78).

Sosyal bilimlerin çevirisindeki kavram ve terim güçlüklerini aşmak için çevirmenin bu tür metinlerle ilişki kurması, bunları erek dile aktarması, başka okumalar yapması, kavramlar arasındaki ilişkileri çözümlemesi, hatta kimi zaman eserin ifade sınırlarını aşarak yaratıcı olması ve yeni kavramlar yaratması gerekir.

Çeviride kavram adlandırması ve terim üretimi iki yolla gerçekleştirilmektedir. Yeni sözcük türetmek için izlenecek yollardan biri mevcut sözcüklere yeni anlamlar kazandırmaktır. Dil içinde sözcüklerin içeriklerinin değişmesi, sözbirimlerin bazı özel alan kullanımlarında terimleşmesi olağan bir olgudur. İzlenecek diğer yol ise elbette terim üretmektir. Fakat Öztürk Kasar'ın da ifade ettiği üzere çoğu zaman çevirmenler, sosyal bilimlerin çevirisi alanında terimlerin sözbirim anlamı kazandıklarına, bir uzmanlık alanından diğer bir uzmanlık alanına kaydıklarına şahit olabilirler (2009:37-38). Bazı durumlarda ise çevirmen, öz Türkçeci bir duruşa sahip olsa bile eski dile ait kimi sözcükleri canlandırarak sorunlara çözüm bulabilir (Öztürk Kasar, 2009: 37-38).

$\mathrm{Bu}$ durumu örneklendirmek açısından "représentation" kavramından söz etmek isteriz. Jean Paul Roux'nun Montagnes Sacrées, montagnes mythiques (1999) adlı eserinde geçen "représentation" kavramı, Mircea Eliade'nin Traité d'histoire des religions (Editions Payot, 1959) adlı eserinde de yer almaktadır. Roux'nun eserinin çevirisi sırasında gerçekleştirilen uzun araştırmalardan sonra, sözü edilen iki eserde yer alan "représentation" kavramının aynı anlam alanını karşıladığı sonucuna varılmış ve aynı karşılıkla çevirilmesine karar verilmiştir. Çünkü Fransızca «représentation» kavramı zihindeki bir kavramın, imgenin temsili, dışavurumu, ortaya çıkışı anlamına gelmektedir3 ve Türkçe'de, eser bağlamında bu kavramla en iyi örtüşen kavram yine "tasavvur" olmaktadır. "Représentation"un karşılığı olarak "tasavvur" daha önce eserin Dinler Tarihine Giriş adlı çevirisinde (2020) kullanılmıştı zira burada da kastedilen dinsel duygu, düşünce ve inancın temsili, dışavurumu, ortaya çıkışıydı. Montagnes Sacrées, montagnes mhytiques'den alıntılanan bir cümleyle durumu somutlaştırmak mümkündür:

Trésor de la langue française,

http://atilf.atilf.fr/dendien/scripts/tlfiv5/visusel.exe?11;s=3392481495;r=1;nat=;sol=0; Erişim tarihi: 16.12.2020

Adres Address

RumeliDE Dil ve Edebiyat Araşttrmaları Dergisi $\quad$ RumeliDE Journal of Language and Literature Studies

Osmanağa Mahallesi, Mürver Çiçeği Sokkak, No:14/8 Osmanağa Mahallesi, Mürver Çiçeği Sokak, No:14/8

Kadıköy - İSTANBUL / TÜRKIYE 34714 Kadıköy - ISTANBUL / TURKEY 34714

e-posta: editor@rumelide.com

e-mail: editor@rumelide.com

tel: +90 $5057958124,+90216773$ o 616 phone: +90 505 7958124, +90 216773 o 616 
Social sciences translations as a category of translation: characteristics, translation facts and professional proficiencies / L. Özcan (pp. 1052-1066)

\begin{abstract}
"De telles affirmations mériteraient d'être nuancées car la montagne n'a pas occupé par tout le même rôle dans l'imaginaire et dans les représentations religieuses. ” (Roux, 1999: 17) 4

"Bu tür açıklamalar dikkatimizi hak ediyorlar çünkü dă̆, din imgeleri ve tasavvurları söz konusu olduğunda her yerde aynı rolü oynamamaktadı»".
\end{abstract}

Sinıflamak ve tanımlamak dışında, terim üretmek konusunda Öztürk Kasar’ın terimsel gereksinim ve yaratııılık düzeyleri şemasından faydalanmanın yararlı olacağı kanısındayız. Zira kimi durumlarda aradığımız karşılık, erek dilde mevcut olabilir, bu durumda başka çarelere başvurmaya gerek kalmadan bu karşılı̆̆ kullanabilir, emek ve zaman tasarrufu sağlayabiliriz. Öztürk Kasar ve Tuna "Sosyal Bilimler Alanında Terimcelerin Çevrilmesi Ve Türkçe Terim Üretimi” başlıklı makalelerinde bu durumu "sıfır gereksinim" olarak tanımlamaktadır (2017:433-434). Bunun dışında, birden fazla karşılığı olan ve bu karşılıkları yaygın olarak kullanılan bir terim için yapılacak en uygun seçim, doğru karşılıkta karar kılmaktır. Tabi bu durumda çevirmen belirli ölçütlere başvurmalıdır: Yaygınlık, bilimsellik, güvenirlik ve işlevsellik. Öztür Kasar ve Tuna, çevirmene birden çok karşılığın bulunması durumunda "birincil gereksinim" koşulunu sağlamayı önermektedir. Kimi zaman çok yaygın bir kullanımı olan bir sözbirimin terim anlamında kullanıldığı olmaktadır. Bu durumda çevirmen birincil gereksinim durumuna uyacak ve bu sözbiriminden bir terim yaratacaktır. "İkincil Gereksinim" ise bir terimin birden fazla karşıllğı olmakla birlikte, çalışılan alanda bu karşılıkların hiçbirinin uyum göstermemesi durumudur ki bu durumda yeni terim yaratmak gerekecektir (Öztürk Kasar, Tuna, 2017:433-434). Son olarak ise "tam gereksinim" durumu vardır:

\begin{abstract}
“Terimler "yerleşiklik" sorunu gösterdiğinde yani bir terimin birden fazla karşılığının dilde aynı düzeyde baskın olması durumunda burada çevirmen uygun bir karşılıkta karar kılmalıdır. Tabi hiçbir karşılık olmaması "tam gereksinim" durumunu doğuracak ve neolojizm süreci başlayacaktır." (2017: 435)
\end{abstract}

Hatta tek bir sözbirimin bir çoklu terime dönüştüğü durumlar da olabilir. Bir örnekle somutlaştırmamız gerekirse: Michel de Certeau'nun Gündelik Yaşamın Keşfi kitabının anahtar kavramlarından biri de "les arts de faire" çoklu terimidir ki eserin alt başlığı da bu şekildedir (Certeau, 2009). Söz konusu çoklu terim hatta tümce-terim, tüketim-üretim zincirini tanımlamaktadır. Günlük tüketim alışkanlıklarının, tutumlarının ve uygulamalarının incelenmesinden oluşur. $\mathrm{Bu}$ tümceterimdeki "faire" sözbirimi ise Fransızca'da sonsuzluk düzeyinde anlama sahiptir. Çeviri sürecinde, "faire" sözbiriminin kavram içindeki karşıllğı düşünülerek, bu sözbirimi Türkçe'de çoklu bir terimle karşılamanın doğru olacă̆ı sonucuna varılmıştır: «eylem, uygulama ve üretim». Dolayısıyla özgün dilinde çoklu bir terim olan terimin içinde ikinci bir çoklu terim yaratarak, okur için terimin anlamını olabilecek en açık biçimde karşılama yoluna gidilmiştir: "Eylem, uygulama ve üretim sanatları".

Sosyal bilimler alanında kullanılan kimi terimler, farklı dönemlerde farklı anlamlar yüklenebilirler; bu durumda terimin sözü edilen zaman dilimindeki karşılı̆̆ını ve anlamını kullanarak, mevcut zamandaki karşılı̆̆ını parantez içinde vermek olası anlam karmaşalarının önüne geçebilir. Ya da terimler bilimsel alandan alana farklı anlamlar yüklenebilir. Bu koşulda, geçerli bilim dalındaki anlamıyla metin içinde kullanılan terimin, diğer alanlardaki karşılık ve anlamları dipnotta okura sunulursa, okurun olası kafa karışıklıklarının önüne geçilmiş olabilir. Veya bir terim, aynı alan içinde farklı kuramcılar tarafından farklı karşılıklarla ele alınabilir. Sündüz Öztürk Kasar'ın kendisinin de katıldığı 2017 yllında Paris’te düzenlenen "Sosyal Bilimlerde Çeviri / Aktarılabilirlik ve Kültürlerüstü İletişim" konulu uluslararası bir kolokyumda, Ladmiral'in çeviribilim alanından bu tür bir duruma net bir örnek verdiğini aktarır (2010:3). Ladmiral, kendisinin isim babalığını yaptı̆̆ "kaynak ve erek odaklılı" (FR:

Makalede, çeviri örnekleri bağlamında çeşitli eserlerden yapılan alıntılar, çevirilerin takip edilebilmesi amacıyla, önce kaynak eserden özgün bölüm, ardından ilgili bölümün Türkçe çevirisi biçiminde verilmiștir.

\title{
Adres $\mid$ Address
}

RumeliDE Dil ve Edebiyat Araşttrmaları Dergisi $\quad$ RumeliDE Journal of Language and Literature Studies Osmanağa Mahallesi, Mürver Çiçeği Sokak, No:14/8 Osmanağa Mahallesi, Mürver Çiçeği Sokak, No:14/8

Kadıköy - ISTANBUL / TÜRKIYE 34714 Kadıköy - ISTANBUL / TURKEY 34714 e-posta: editor@rumelide.com

e-mail: editor@rumelide.com

tel: +90 505 7958124, +90 216773 o 616 phone: +90 505 7958124, +90 2167730616 
sourciers/ciblistes)" terimini ele alarak, Toury'nin bu ikiliğin tanımladığı olguyu "kabul edilebilirlik/yeterlik" olarak adlandırdığını, Venuti'nin ise "yabancılaştırma/yerlileştirme" olarak dile getirdiğini belirtir (aktaran Öztürk Kasar, 2010:3).

Pek çok kuramcının da belirtiği gibi sosyal metin çevirileri dilsel maharetin en üst noktalara ulaştı̆̆ çeviri örnekleri sunan çeviri türüdür. Örneğin ruhbilim, toplumbilim gibi derin gözlem ve incelemelerin özellikle anlatı düzeyinde verildiği bilimlerde, sözcük oyunlarının ve kavramların geçişgenliğinin çevirmenlere yaratıcılıklarını kullanacakları firsatlar verdikleri görülür. Bu bağlamda René Girard'ın Achever Clausewitz (2007) isimli eserinin çevirisinde karşımıza çıkan bir terimden söz etmek yerinde olacaktır. Eserde Girard daha önce geliştirmiş olduğu "üçgen arzu modeli" kuramından bir kavrama başvurmaktadır. Kavramı tanımlamadan önce "üçgen arzu modeli”nin kısa bir tanımlamasını yapmak yerinde olacaktır. Rene Girard, Romantik Yalan ve Romansal Hakikat: Edebi Yapıda Ben ve Öteki5 adlı kitabında "üçgen arzu modeli” olarak kavramlaştırdığı kuramı açıklamıştır. Bu kurama göre, Girard, arzunun kendiliğinden doğmadığını, kişide arzu duygusunun doğmasına ve dışa vurumuna yol açan etkenlerin olduğunu belirtir ve bu etkenleri üçgen bir modelle açılar. Bu üçgen modele göre bu etkenler özne, arzu nesnesi ve bu arzuyu doğuran ya da açı̆̆a çıkaran dolayımlayıcıdır (2020). Achever Clausewitz eserinde yazar bu kuram içindeki önemli bir kavramı kullanır: "modèle-obstacle" (Girard, 2007:43 vd.) Yine kısaca anlatmamız gerekirse bu terim, kişinin arzu duyduğu ancak kendisini gerçekleştirmesine engel olan, gıpta ettiği bir özne-modeli tanımlamaktadır (Girard, 2007:43 vd.). Çeviri sırasında gerçekleştirdiğimiz araştırmalar sırasında karşılaştığımız mevcut Girard çevirilerinde ${ }^{6}$ bu kavramı karşılayabilecek Türkçe bir çeviriye rastlayamayınca, yeni bir karşıllk geliştirmeye karar verdik. Terimdeki "modèle" sözbirimi Türkçe'ye zaten "model" olarak geçmiş bulunuyordu. "Obstacle" için tanıma uygun bir karşılık bulma arayışımızda "tökezlemek” sözbirimi dikkatimizi çekti. Zira “tökezlemek”, TDK Genel Türkçe Sözlük’te "Yürürken ayağı bir yere çarpıp sendelemek" ve "güçlük ve engellerle karşllaşmak" anlamlarına sahip olarak tanımlanmaktad17. Bu anlamların Fransızca'daki "obstacle" sözbiriminin anlamların karşıladığını ve okurun gözünde bu modelin kişiyi nasıl yolundan alıkoyduğunu çok iyi görselleştireceğini düşünerek, "tökez" sözbiriminin bu terimi karşllamakta uygun olacağını ve satır altında da "tökezlemek, tökezletmek, engel olmak, karşısına dikilmek" anlamlarını da anıştıracağını düşünerek yeni bir terim üretmiş olduk: "tökez-model”.

Terim çerçevesi içinde ele alınabilecek bir diğer alt başlık da özel adlar olabilir. Özellikle tarihteki olay, kurum ve şahıs adlarının ve tabi ki yer adlarının çok önemli olduğu tarih, etnoloji, arkeoloji vb. bilim dalları için özel ad çevirisi konusunda çevirmenin çok bilinçli bir araştırma yürütmesi gerekir. Zira özel adlar bir coğrafyadan başka bir coğrafyaya, bir kültürden başka bir kültüre hatta bir zaman diliminden başka bir zaman dilimine her türden farklılıklar gösterebilir: Yazımsal, anlamsal, kavramsal ve yananlamsal boyutta. Bu tür durumlarda çevirmen bir tarih bilimci hassasiyetinde çalışmalı, araştırmalı, güvenilir kaynaklardan yararlanmalı ve belirli bir tutarlılık, bütünlük bilincine sahip olmalıdır. Tek bir cümlede karşılaşılan özel adların çevirisiyle günler hatta haftalar boyunca uğraşmak zorunda kalınabilir. Bu durumu yine Montagnes Sacrées, montagne mythiques eserinden örneklendirebiliriz:

\footnotetext{
5 René Girard'ın bu kuramı açıkladığı ilk eseri olan Mensonge romantique et vérité romanesque 1961'de Editions Grasset'den yayımlanmıștır. Eserin daha sonra pek çok yeniden basımı ve çevirisi olmuştur. Eserin Türkçe basımı Arzu Etensel İldem'in çevirisiyle 2001 ylında Metis yayınları tarafından gerçekleştirilmiştir.

6 Eserin çevirisi sırasında yararlandığımız ilgili kaynaklar, Șiddet ve Kutsal (Çev. Necmiye Alpay, 2003, Kanaat Yayınevi), Romantik Yalan ve Romansal Hakikat (Çev. Arzu Etensel İldem, Ayrıntı, 2001), Günah Keçisi (Çev. Işık Ergüzden, 2005, Kanaat Yayınevi)'dir. Türk Dil Kurumu, Türkçe Genel Sözlük, https://sozluk.gov.tr/ , Erişim tarihi 13.12.2020.

Adres $\mid$ Address

RumeliDE Dil ve Edebiyat Araşttrmalar Dergisi $\quad$ RumeliDE Journal of Language and Literature Studies Osmanağa Mahallesi, Mürver Çiçeği Sokak, No:14/8 Osmanağa Mahallesi, Mürver Çiçeği Sokak, No:14/8 Kadıköy - İSTANBUL / TÜRKIYE 34714 Kadıköy - ISTANBUL / TURKEY 34714 e-posta: editor@rumelide.com e-mail: editor@rumelide.com, tel: +90 505 7958124, +90 2167730616 phone: +90 505 7958124, +90 2167730616
} 
Social sciences translations as a category of translation: characteristics, translation facts and professional proficiencies / L. Özcan (pp. 1052-1066)

\begin{abstract}
"Tant le ciel plutôt que l'Olympe". Il est significatif qu'elle ait porté peu d'intérêt aux Apennins et qu'elle ait négligé le Vésuve malgré sa beauté et son activité volcanique. Elle ne s'est intéressée qu'enpassant à quelques autres cimes -le Monte Circello, alors promontoire de Circé, le mont SaintSylvestre qu'elle nomme le Saracte et place sous la protection d'Apollon - et s'est contentée d'exalter «les sept montagnes enfermées dans l'enceinte de l' Urbs », de bien grands noms pour de bien petites collines : le Palatin s'élève à 51 mètres, le Capitole à 49 mètres, le Quirinal à 69 mètres**” (Roux, 1999: 18)

“Antik Roma sadece birkaç zirvenin adını geçirir -Circeo Dağı, Kirke burnu ve Apollon'un koruması altında bulunan Saint-Slyvestre Dağl- ve “Urbs civarındaki yedi dağı” yüceltmekle yetinir; küçücük tepeler için oldukça cüretkar adları vardır: Palatino Tepesi 51 metre, Capitol Tepesi 49 metre, Quirinal Tepesi 69 metre yüksekliğindedir**."
\end{abstract}

Özel ad çevirileri, yazınsal çeviri, tiyatro oyunlarının çevirisi ve hatta sözlü çeviri vb başka çeviri türleri boyutunda da tartışlabilecek özel bir çeviri olgusudur. Konumuz dahilinde de özellikle tarih metinlerinin çevirisi söz konusu olduğunda özel ad çevirileri, çok farklı sorunsalları, zorlukları ve özellikleri ortaya koyabilir. Özel ad çevirileri gibi hemen hemen tüm çeviri türlerinde ve elbette sosyal bilimlerin çevirileri özelinde de ele alınması gereken bir başka konu da bağlam konusudur.

\title{
4.2. Sosyal bilimlerin çevirilerinde bağlam olgusu
}

Bağlam olgusu, yazınsal üretimden dilbilim ve göstergebilime, toplumbilimden antropolojiye kadar pek çok insan biliminin ve yazın, dil, söz ve metin üretim alanının üzerinde durduğu önemli bir olgu olmuştur. Sosyal bilimlerin çevirisi çerçevesinde ise Bourdieu'nün ifadesiyle bağlam yaşamsal bir öneme sahiptir ki bunun yokluğu yanlış anlamalara yol açmaktadır:

\begin{abstract}
"Bu metinlerin bağlamdan soyut bir şekilde dolaşıma çıktı̆̆ı bir gerçektir...bu nedenle bu metinlerin alımlama alanının yapısına göre yeniden yorumlanması muhteşem yanlış anlamalara yol açmaktadır." (Bourdieu, 2002:4).
\end{abstract}

Yine bu durumu görünür kılmak açısından, Sapiro’nun vermiş olduğu bir örneğe yer vermek isteriz. Sapiro'nun ifadesiyle, Habermas, Almanya'da bir toplumbilimci olarak algılanırken, Fransa'da bir felsefeci olarak görülmektedir (Sapiro, 2012:14). Dolayısıyla çeviri metinler, varış kültüründe yeniden algılama, (hangi seride basıldığına, hangi yazarın önsözde ne yazdığına, sonsözlerin niteliğine göre değişen) etiketleme, ilhak, varış uzamının kendine özgü mantığıyla işleyen anlamlandırma, alımlama ve konumlandırma sürecine girmektedirler (Sapiro, 2012). Çevirmen, bu noktada güçlü bir okuma etkinliğine girişmiş olması, sadece yazarın değil, eserin ufkunu oluşturan tüm külliyata gitmesi gerektiğinin farkında olmalıdır. Bu açıdan örneklendirebileceğimiz bir eser de René Girard'ın Achever Clausewitz eseridir (Girard, 2007). Pek çok bilimdalının kavşağında yazarın kimliğini yoğun olarak vurgulayan bu eserde iki farklı bağlam için de Girard tek bir terim kullanmaktadır: "échange”. Bu sözbirimi Fransızca'da çok farklı anlamlara gelebilmektedir ama en sık rastlanılan anlamları "alışveriş, değişim ve ticarettir" . Ancak "échange” özellikle ekonomi bağlamında Türkçe'de "ticaret" anlamıyla yer bulmaktadır. Girard'ın insanların karşıllklılık ilişkisi içinde birbirlerinden alıp verdikleri maddi ve manevi sermayeyi tanımlamak için "échange" terimini kullandığında bunun Türkçe olarak "değiş̧ tokuş" kavramını ifade ettiği, ancak maddiyata dayalı bir değiş tokuştan söz ettiği durumlarda "alışveriş" kavramını dile getirdiği eserin ve ilgili bölümlerin bağlam çözümlemesinden çıkarılmıştır. Üstelik Girard bazı bölümlerde “ticaret” sözbiriminin Fransızca'da yaygın olarak kullanılan karşılığını “commerce” sözbirimini kullanmaktadır9. Dolayısıyla çeviride, iki farklı anlam (ticaret ve her tür değiş

Trésor de la langue française informatisée,

http://atilf.atilf.fr/dendien/scripts/tlfiv5/visusel.exe?36;s=4127822445;r=2;nat=;sol=1; Erişim tarihi: 13.12.2020.

Trésor de la langue française informatisée, http://atilf.atilf.fr/dendien/scripts/tlfiv5/advanced.exe?79;s=4127822445; Erişim tarihi: 13.12 .2020 .

RumeliDE Dil ve Edebiyat Araşttrmaları Dergisi Osmanağa Mahallesi, Mürver Çiçeği Sokak, No:14/8 Kadıköy - ISTANBUL / TÜRKIYE 34714 e-posta: editor@rumelide.com tel: +90 $5057958124,+902167730616$
Address

RumeliDE Journal of Language and Literature Studies

Osmană̆a Mahallesi, Mürver Çiçeği Sokak, No:14/8

Kadıköy - ISTANBUL / TURKEY 34714

e-mail: editor@rumelide.com,

phone: +90 5057958124 , +90 2167730616 
tokuş faaliyeti) için tek bir terim kullanılmak durumunda kalınmıştır. $\mathrm{Bu}$, aslında sosyal bilimlerin çevirisinde çok karşılaşılan hatta tavsiye edilen bir durum değildir. Terimi somutlaştırmak için eserden çevirisini yapmış olduğumuz bir bölümü örnek olarak gösterebiliriz.

"La guerre et l'échange

B. C. : Faut-il en conclure que la conception que Clausewitzse fait de l'action réciproque (Wechselwirkung), c'est-à-dire du commerce entre les hommes, commerce marchand ou relation guerrière, implique ainsi l'aperception du duel comme structure cachée de tous les phénomènes sociaux" (Girard, 2007:113)

"Savaş ve Değiş Tokuş

B.C.: Buradan şu sonucu çıkarmak mı gerekli: Clausewitz'in karşılıklı eylem (Wechselwirkung) tanımı yani insanlar arasındaki alışveriş, ister ticari alışveriş olsun ister askeri anlamda alışveriş olsun, düellonun, tüm toplumsal görüngülerdeki gizli yapı olduğunun anlık bir idraki midir?”

Dolayısıyla bağlam olgusu sosyal bilimlerin çevirilerinde çok boyutlu ve geniş bir yelpaze içinde düşünülmelidir. Sadece yazar ve eserin yer aldığı bilimsel uzam değil bu eserin gönderme yaptığı, alıntıların yapıldığı, anıştırdığı diğer yazarlar ve bu yazarların ilgili eserleri ve bilimler arası uzam özgün eserin bağlamını oluşturmaktadır.

\subsection{Sosyal bilimlerin çevirilerinde biçem olgusu}

Kesin bilimler ya da temel bilimlere kıyasla sosyal bilim metinlerinin yazı dilinin daha yazınsal ifadelere sahip olduğu gözlemlenmektedir. Bu metinlerde biçemin kimi zaman tarihsel bir boyutu bile vardır. Sosyal bilimlerin metinlerinin biçemi yazınsal metinler kadar anlatımsal özellikler taşıyabilir. $\mathrm{Bu}$ metinlerde sık sık eğretileme, taşlama, güzelleme vb. söz ve sözcük oyunlarına, deyiş ve ifadelere hatta ses oyunlarına rastlamak mümkündür. Dolayısıyla, bu metinlerde de tıpkı yazın eserlerinde olduğu gibi, "söylemi öznesinden bağımsız değerlendirmek mümkün değildir" (Öztürk Kasar, Tuna, 2017: 421).

Aslında özelde yazınsal ama hemen her çeviri türü için geçerli olan bu ifade, sosyal bilimlerin çevirisi alanında farklı bir anlam daha kazanmaktadır. Yazarın sadece çevirisini yaptığı kitabından değil tüm kitaplarından, makalelerinden ve sözlerinden sorumludur çevirmen; zira çevirisini yaptığı kitap bütün bu eserlerin oluşturduğu düşünsel ve bilgisel bir birikimin sonucunda ortaya çıkmıştır ve bunlarla organik bir bağı vardır. Ve hatta özyaşamöyküsünün devinimlerinin de bu üretimde büyük payı olduğu söylenebilir. $\mathrm{Bu}$ nedenle çevirmeni, yazarla sadece ruhsal ve duygusal bir özdeşleşmenin kimi durumlarda yeterli olduğu yazınsal çeviriden fazla olarak düşünsel bir özdeşleşme süreci de beklemektedir.

Bu açıdan biçemsel özelliklerin sosyal bilimlerdeki etkisine Jean Paul Roux'nun eserlerinden örnekler verilebilir. Roux'nun daha didaktik bir özellik taşıyan tarih incelemelerindeki dili ve biçemi (örneğin Orta Asya Tarihi, Türklerin Tarihi vb.), daha gizemci, felsefi ve derin bir bakış açısıyla kaleme aldığı eserlerindeki dil ve anlatım düzeyinden (Kutsal Bitki ve Hayvanlar ve Montagne sacrées, montagnes mythiques'de olduğu gibi) farklı olmaktadır. Daha kişisel, duygusal ve yoruma dayalı eserlerinde takındığı duruş, tavır ve söz ağırlığı ise çok daha farklıdır (Dinlerin Çarpışması bu tür biçeme örnek olarak gösterilebilir). René Girard'ın özellikle yazınsal çözümleme alanındaki kitaplarındaki söz, dil ve biçeminin, Achever Clausewitz'deki söz, dil ve biçeminden ayrıldığını gözlemleyebilmiştik. Gördüğümüz kadarıyla yazarın bu eserdeki aydınlanma, vahiy göndermelerine ve gizemci ve derin psikolojik bakış açısına diğer eserlerinde belli belirsiz rastlanmaktadır. Achever Clausewitz'de bu

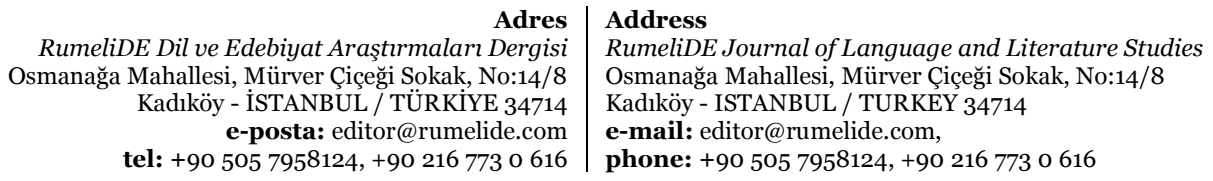


Social sciences translations as a category of translation: characteristics, translation facts and professional proficiencies / L. Özcan (pp. 1052-1066)

tavrın neredeyse yazarın İsa Mesihçi olarak yorumlanmasına kadar gidebileceğini söylemek mümkündür.

\begin{abstract}
"Le moment décisif de cette évolution est constitué par la révélation chrétienne, sorte d'expiation divine où Dieu en son Fils demanderait pardon aux hommes de leur avoir révélé si tard les mécanismes de leur violence. Les rites les avaient lentement éduqués, les hommes allaient dorénavant devoir s'en passer." (Girard, 2007:10)

“Bu evrimin mihenk anı ise Hıristiyan aydınlanma anı, Oğulun doğasına bürünmüș Tanrı’nın insanlardan doğalarındaki şiddet mekanizmalarını bu kadar geç onlara vahiy ettiği için özür dilediği, yani günahların kefaretinin ödendiği o andır. İşte ayinler bu mekanizmaları bize yavaş yavaş öğretirler, öğretiler ki insanlar bunları tekrar etmesinler.”
\end{abstract}

Dolayısıyla sosyal bilimlerin çevirilerinde, eserin sadece bilgi, düşünce, terim ve kavram yönünden dikkatli ve yoğun bir söylem çözümlemesinden geçirilmesi yeterli olmamaktadır. Tıpkı yazın çevirilerinde olduğu gibi sosyal bilimlerdeki özgün metinlerin yazınsal açıdan da dil, ifade, deyiş ve söz özellikleriyle çözümlenmesi gereksinimi vardır. Bu çok boyutlu söylem çözümlemesinin ardından çevirmen nihayetinde bir bilgi ve bilim metni çevirdiğinin farkında olmakla birlikte bir yazara ait bir "sözü" yani bir "biçemi” çevirdiğinin de bilincinde olmalıdır. Bu bilinçle hareket eden bir çevirmen, çevirisinde, özgün metinin biçemini, sözünün özelliğini koruyan bir biçem yaratması gerektiğinin farkında olabilecektir. Zira sosyal bilimlerin çevirilerinde söz konusu olan sadece bilim, düşünce ve bilgi aktarımı değildir, erek okurda aynı etkinin yaratılması "yazar-biliminsanları" için önemlidir. Çevirmen, özgün eserin yazarına bu saygıyı göstererek eseri bir bütün olarak erek uzama taşıyabilir.

\title{
4.4. Sosyal bilimlerin çevirilerinde erek kitle olgusu
}

Öncelikle her çeviri türünde kaynak metin kitlesi ile erek metin kitlesi arasında uzamsal, zamansal ve kültürel ve elbette dilsel bir kayma, ayrım olduğu açıktır ancak Bourdieu'nün de ifade ettiği üzere sosyal bilimlerin çevirileri, özgün metnin yöneldiği beklentilerden farklı beklentilerle alımlanırlar, bu da özgün metinden daha serbest, daha farklı ve daha özgün okumaların ve yorumların kapılarını aralar (Bourdieu, 2002). Bu nedenle sosyal bilimlerin çevirmeni, özgün metin okurunun üzerinde yaratılan etkiden çok kendi kültüründe ve uzamında oluşturmuş olduğu metnin etkisi üzerine odaklı olabilir.

Schögler'in, Bennett'ten verdiği bir örnekle durumu açlklarsak, Foucault'nun Fransız felsefesini temel aldığı bilinmektedir (Canguilhem, Bachelar, Lacan) ve bu felsefeciler İngilizce diline ait düşünsel uzamda çok bilinen, alıntılanan düşünürler değildirler. Dolayısıyla Foucault'nun İngilizce'ye çevirisi, Fransızca Foucault'yu kendi bağlamından tamamen soyutlamış, bağlamsız bir Foucault yaratmıştır. (aktaran, Schögler, 2017: 38-39)

Dolayısıyla alandaki bir diğer zorunluluk, çevirmenin, erek kitlesinin niteliklerini ve yeterliliklerini gözden kaçırmamasıdır. Sosyal bilimlerin metinleri, kaynak dil kullanıcıları için bile, karmaşık bir biçeme ve dile sahip, kolay okunamayan, ağır bilgi yükü taşıyan metinlerdir. Bu nedenle çevirmen erek dilde, kavram ve olguları açınsamaya, "çevrilemezlik" güçlüğüyle baş etmeye çalışmalıdır. Buradaki genel anlayış erek kitleden yana tavır almak olarak açımlanabilir.

Bu duruma bir örnek Girard'ın Achever Clausewitz eserinden verilebilir. Girard, eserinde bir yerde Clausewitz'in çok özel bir savaş tanımına ve adlandırmasına değinmektedir. Clausewitz savaştan "l'étrange trinité" olarak söz etmektedir (Clausewitz, 1955:69). Bu noktada belirtmemiz gereken önemli bir husus, Girard'ın, bu kavramı özgün dili Almanca olan eserin Fransızca çevirisinden aldığıdır. Clausewitz’in eserinin bizim de yararlandığımız Almanca'dan yapılan Türkçe çevirisinde bu

\footnotetext{
Adres $\mid$ Address

RumeliDE Dil ve Edebiyat Araşttrmaları Dergisi $\quad$ RumeliDE Journal of Language and Literature Studies Osmanağa Mahallesi, Mürver Çiçeği Sokak, No:14/8 Osmanağa Mahallesi, Mürver Çiçeği Sokak, No:14/8 Kadıköy - ISTANBUL / TÜRKIYE 34714 Kadıköy - ISTANBUL / TURKEY 34714 e-posta: editor@rumelide.com e-mail: editor@rumelide.com, tel: +90 505 7958124, +90 2167730616 phone: +90 505 7958124, +90 2167730616
} 
kavram "üç çekim merkezi” olarak karşllanmıştır (Clausewitz, 2013: 47-48). Ancak Fransızca'daki karşılığı olan "trinité" sözbirimi, aynı zamanda Hıristiyanlıktaki çok önemli bir inancı tanımlayan dinsel bir terimdir. Türkçe'de "teslis" olarak karşılanan "trinité" Hristiyanlıkta "Tanrı, İsa ve Kutsal Ruh'un aynı kişi olmaları inancı, üçleme” anlamına gelmektedir ${ }^{10}$. Girard ise kendi eserinde, buradaki sözbirim benzerliğinin altını çizerek buradan bir yorum üretmektedir ve Frankofon okurun bu tercihteki dinsel anlamı da görmelerini sağlamaktadır. Bu nedenle çeviride Türkofon okurun da aynı göndermeyi kurabilmesi için Clausewitz'in bu terimini, Türkçe'deki mevcut karşllığını muhafaza ederek değil, Fransızca'daki karşılığı esas alarak çevirme kararı alınmıştır. Buradaki seçimde erek okurun niteliği ve okur için anlaşılır, net ve açıklayıcı bir çeviri oluşturma gayesi etkili olmuştur.

\section{Mesleki yeterlilikler}

Sosyal bilimlerin çevirisi alanında çalışan bir çevirmenin sahip olması gereken mesleki yeterlilikler yukarıda kısaca aktarmaya ve örneklendirmeye çalıştığımız alana özgü zorlukların üstesinden gelebilecek yetkinlikleri, gerekli çeviri yöntemlerini geliştirebilecek bilgi ve becerileri kapsamalıdır.

Sosyal bilimler çevirmeni, alanın mutfağından çıkmış, "mektepli” bir uzman olmalıdır. Zira alanın getirdiği söylemsel ve biçemsel sorunlar, çevirmenin kuramcıyla aynı düzlemde buluşmasını gerektiren bir özdeşleşme süreciyle aşılabilir, çevirmen kuramsal biçem kurgusuna hakim olmalıdır. Bu doğrultuda Öztürk Kasar’nn da açıklıkla tanımladığı gibi sosyal bilimler çevirmeni, yetkin bir okur ve titiz bir söylem çözümleyicisi olmalıdır (2017). Zira bu tür metinlerin getirdiği tüm o kuramsal ve kavramsal anlam ağını ilmik ilmik çözmekle kalmayıp, bu anlam kavrama aşamasını savlama ve akıl yürütme mantığını iyi tanıyan, bu mantığı bizzat kullanan "bir söylem çözümlemecisi olmalıdır aksi halde tüm anlamı gözden yitebilir” (Öztürk Kasar, 2017: 314-315).

Alanın getirdiği uzmanlık boyutu düşünülünce elbette iyi bir terim araştırmacısı ve yetkin bir terim üreticisi olmak gereklidir. Çevirmen bu dilsel sorunlarla baş edebilmek için net bir dil bilincine, yetkin bir dil kullanımına, yaratıcı bir dil dehasına sahip olmalıdır ve Öztürk Kasar’ın ifadesiyle “dilbilim ve terimbilim eğitimi almış olmalıdır" (Öztürk Kasar, 2017: 314-315).

Biçem ve bağlam sorunlarına değindiğimizde açıkça ortaya çıktığı gibi sosyal bilimler söylemi üretmek düz bir metin üretiminden çok farklıdır. Dolayısıyla bu tür bir metnin çevirisini üstlenecek çevirmenin de tıpkı yazın metinlerinde ileri sürüldüğü gibi güçlü bir kaleme sahip olması gereksinimi vardır. Zira kuramsal, bilgi iletimi içeren metinlerin de kendine özgü bir biçemi vardır; bu biçemi verebilmek için çevirmenin de bu metinlerin ifadelerine hakim olması beklenir.

Tabi tüm bu zorlukların üstesinden gelmeye çalışacak bir çevirmenin Öztürk Kasar'ın ifadesiyle "cesur ve azimli bir kiş̧” olması çok sözü edilmeyen önemli bir özelliktir (2017:314-315). Tüm çeviri türleri için söylenebilecek bu özellik sosyal bilimler çevirmeni özelinde farklı bir çağrışıma sahiptir çünkü gözlemlendiği kadarıyla tüm çeviri türleri içinde yoğun olarak sosyal bilimlerde çeviri yapan bir çevirmen, diğer çeviri türlerindeki meslektaşlarına oranla daha az görünür olmakta, daha az takdir edilebilmektedir. Dolayısıyla da daha az maddi kazanç sağlayan çevirmenler olmaktadırlar. Bu nedenle yukarıda sözü edilen "azim” ve "cesarete" "meslek aşkını" da eklemek yerine olacaktır düşüncesindeyiz.

10 Trésor de la langue informatisée,

http://atilf.atilf.fr/dendien/scripts/tlfiv5/advanced.exe?224;s=4127822445; Erişim tarihi: 13.12.2020.

Adres Address

RumeliDE Dil ve Edebiyat Araşttrmaları Dergisi $\quad$ RumeliDE Journal of Language and Literature Studies

Osmanağa Mahallesi, Mürver Çiçeği Sokak, No:14/8 Osmanağa Mahallesi, Mürver Çiçeği Sokak, No:14/8

Kadıköy - İSTANBUL / TÜRKIYE 34714 Kadıköy - ISTANBUL / TURKEY 34714

e-posta: editor@rumelide.com

e-mail: editor@rumelide.com,

tel: +90 $5057958124,+90216773$ o 616 phone: +90 505 7958124, +90 216773 o 616 
Social sciences translations as a category of translation: characteristics, translation facts and professional proficiencies / L. Özcan (pp. 1052-1066)

$\mathrm{Bu}$ noktada sanırız akademisyen-çevirmenlerin önemi ortaya çıkmaktadır. Zira alanda söz konusu olan, dili çevirmekten ziyade düşünceyi çevirmektir. Ve yukarıda sözü edilen hasletleri en çok bünyesinde toplayan meslek erbapları akademisyen-çevirmenler olmaktadır kanısındayız.

$\mathrm{Bu}$ özelliklere ek olarak Ergüden, çevirmenlerin nesnel, dikkatli ve bilimsel duyarlılı̆̆ yüksek olmalarını belirtmektedir:

“Aynı düşünceler paylaşılmıyor olsa bile kendi bildiklerimizden ziyade yazarın dediklerine odaklanmak [...] yani ha varoluş, ha varlık, ha mevcudiyet ne fark ederci olmamak... terimsel tutarlılık bilincinde olmak, [...] her bağlama özgü sorunlar olduğunun ve bağlama özgü çözümler gerektirdiğinin farkında olmak.. " (Ergüden, 2015).

Bu nedenle çevirmen, kaynak dile özgü güçlüklerden ziyade çevirmeni olduğu uzmanın ya da biliminsanının söylemine hakim olabilmek için çok güçlü, geniş ve yetkin bir kaynakça oluşturmalıdır (Berrichi, 2012:22). Yani tıpkı teknik çeviri alanında olduğu gibi çevirmenin, nasıl araştırma yapacağını, yetkin araştırma modellerini biliyor olması ve danışman ve uzmanlara ulaşma ve onlardan bilgi alma maharetine sahip olması alanın bir diğer belirleyici unsurudur (Berrichi, 2012:22).

\section{Sonuç ve öneriler}

Schögler’in de ifade ettiği gibi, sadece edim olarak değil aynı zamanda bu edimin sonuçlarının ve etkilerinin toplum yaşamına doğrudan etkisi olması dolayısıyla da sosyal bilimler alanındaki çeviri etkinliklerinin ayrı bir önemi olduğunu düşünüyoruz (Schögler, 2017: 37). Bourdieu'nün işaret ettiği gibi sosyal bilimlerin çevirisi, net bir bağlam değişimi sağlayan bir metindir ve özgün metinin üretim alanının önyargılarından çok uzak bir okumanın alanıdır. Bu yönüyle sosyal bilimlerin çevirisi bir “markalama” alanıdır, düşüncelerin ve metinlerin markalamasını yapar (Bourdieu, 2002: 5).

Ayrıca bu çeviri metinlerin araştırılmasının çeviribilimde yeni ufuklar açacağı düşüncesindeyiz. Aynı çerçevede, Schögler de çevirinin, dönüştürücü gücünün en açık olarak kendini gösterdiği çeviri türünün sosyal bilimler çevirileri olduğunu belirtmektedir (Schögler, 2017: 42). Zira bu çeviriler, düşünsel alanın yapısını dönüştürme kapasitesine sahiptir. Emile Durkehim çevirilerinin Türkiye'de sosyoloji biliminin temelini oluşturması (Özcan, Vergili, 2017), Berke Vardar'ın Ferdinand de Saussure çevirilerinin dilbilim alanını oluşturması gibi (Öztürk Kasar, 2018b). Dolayısıyla çevirmenler, editörler ve yayınevleri bir ülkenin siyasal, toplumsal ve bilimsel aktörleri kadar bu alanların oluşumuna katkı verirler. Sosyal bilimlerin çevirilerinin önemini Ergüden’in sözleriyle bir kez daha hatırlatmanın yerinde olacağı kanaatindeyiz:

"bu tür metinleri çevirmenin , aktarmanın, tek bir kişiye dahi olsa ulaşmanın önemine inanıyorum. Bunu başka bir dünyayı, başka bir hayat tarzını mümkün kılmanın olası yollarından biri olarak görüyorum. Bu yüzden inadına kitap, inadına düşünce, inadına felsefe,ve sosyal bilimlerin demekten başka çare yok sanırım...” (Ergüden, 2015).

Bu bağlamda sosyal bilimlerde çevirilerin terim ve kavram aktarımı, bağlam, biçem ve erek kitle gibi çeviri olguları özelinde de kendilerine özgü belirgin özellikler taşıdığı sonucuna varılmıştır. $\mathrm{Bu}$ alandaki çevirilerin özelliklerinin belirlediği çeviri zorlukları, sorunsalları, yine bu alanın niteliklerine uygun çeviri yöntemleriyle ele alınabilir ve çözümler üretilebilir inancındayız.

Makalemizin son bölümünde, alanın kendine özgü hasletleri, özellikleri ve sorunsalları düşünülerek sosyal bilimlerde çeviri alanının gelişmesi için, kimi önerilerde bulunmanın, bu alanda gerçekleştirilecek çalışmalara bir nebze katkı sağlayabileceği inancındayız.

\footnotetext{
Adres $\mid$ Address

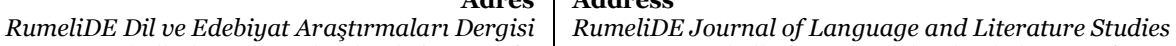
Osmanağa Mahallesi, Mürver Çiçeği Sokak, No:14/8 $\quad$ Osmanağa Mahallesi, Mürver Çiçeği Sokak, No:14/8 Kadıköy - İSTANBUL / TÜRKIYE 34714 Kadıköy - ISTANBUL / TURKEY 34714 e-posta: editor@rumelide.com e-mail: editor@rumelide.com, tel: +90 505 7958124, +90 2167730616 phone: +90 505 7958124, +902167730616
} 
Çalışmamızda mesleki yeterlilikleri tanımlarken sosyal bilimler çevirmenlerinin uzmanlaşmasından söz edilmişti. Bu noktada uzmanlaşmaya ihtiyaç duyan bir aktör de "editörlerdir" kanımızca. Ergüden’in de belirttiği gibi bilim kitaplarının editörlüğü ve redaktörlüğü alanında da uzmanlaşmış iş gücüne ihtiyaç vardır (Ergüden, 2015). Bu alanda uzman çevirmenler yetiştirilmesinin önemi ortaya çıkmaktadır. Ayrıca buna eşgüdümlü olarak tüm insan bilimi dallarında çeviri eğitimi verilmesinin de araştırmacıların farkındalığını artırması açısından kaydadeğer etki yaratacağı düşüncesindeyiz.

Sapiro'nun (Sapiro, 2012:10) ve Berrichi'nin de ifade ettiği üzere (Berrichi, 2012:21) bu alanda var olan bir diğer engel, mevcut bir önyargının ve algının kurduğu uluslararası düzeydeki baskıdır: Bu baskı, başka ülkedeki araştırmacılara ulaşmanın yolu olarak İngilizce yayın yapmak zorunluluğudur. Oysa bilinen ama çok dile getirilmeyen bir gerçek, bilimsel bir araştırmanın, araştırmacının diliyle, dili için, dili içinde gerçekleştirilmesi ve yayınlanması zorunluluğudur. Gerçek yetkin paylaşım ancak bu yolla mümkündür. Aktarım ise bu işin yüzyllardır süregelen uzmanlarına "çevirmenlere" bırakılmalıdır kanaatindeyiz.

Sosyal bilimlerin üretimi ve paylaşımı ve yayılımı alanı ekonomik kısıtlamalardan kurtulursa gelişimin önü açılabilir. Devletlerin, resmi kuruluşların bu alana teşvik vermesi bu yöndeki kısıtları aşabilir. Zira ancak bu biçimde uzman çevirmenler emeklerinin hakkını veren bir değere sahip olabilir ve gerçek anlamda kaliteli çevirilerin yolu açllabilir. Düşüncenin özgürlüğü bu destura bağlıdır inancındayız.

\section{Kaynakça}

Aksoy, B. (1999). Sosyal bilimlerinler Metinleri Çevirisi. Hacettepe Üniversitesi Edebiyat Fakültesi Dergisi, (16:2), ss. 21-27. https://dergipark.org.tr/tr/download/article-file/611195. Erişim tarihi 20 Şubat 2020.

Berrichi, A. (2012). La traduction en sciences sociales. Traduire, (227), 16-28. http://journals.openedition.org/traduire/467 . DOI: 10.4000/traduire.467. Erişim tarihi 3 Şubat 2020.

Bourdieu, P. (2002). Les conditions sociales de la circulation internationale des idées. Actes de la recherche en sciences sociales, 145(5), 3-8. DOI:10.3917/arss.145.0003. Erişim tarihi 3 Şubat 2020.

Clausewitz, C.V. (1955). De la guerre. trad. Denise Naville. coll. « Arguments». Paris:Minuit.

Clausewitz, C.V. (2013). Savaş Üzerine. Çev. Selma Koçak. İstanbul:Doruk.

De Certeau, M. (2009). Gündelik Hayatın Keşfi I / Eylem, Uygulama, Üretim Sanatları. Ankara:Dost.

Ergüden, I. (2015). Bir Çevirmenin Deneyimiyle Türkiye'de Sosyal Bilim Yayıncıllğı. 30 Kasım 2015 Çevbir internet sitesi. http://cevbir.org.tr/yazi-yorum/bir-cevirmenin-deneyimiyle-turkiyedesosyal-bilim-yayinciliği (Bu yazı, Ergüden'in 20 Kasım 2015'te IFEA'da yapmış olduğu konuşmanın metnidir). Erişim tarihi 17 Ocak 2020.

Girard, R. (2007). Achever Clausewitz. Paris:Carnets Nord.

Girard, René (2020). Romantik Yalan ve Romansal Hakikat: Edebi Yapıda Ben ve Öteki. Çev. Arzu Etensel İldem. (ílk basım 2001). İstanbul:Metis.

Özcan L., Vergili A. (2017) The Role of Translation in the Birth of Sociology in Turkey Bibliography of Turkish Translations of the Works of Emile Durkheim. Turkish Studies. (12), 43-64. http://www.turkishstudies.net/DergiTamDetay.aspx?ID=12305

Öztürk Kasar, S. (2009). Dilde Kavramsal Gelişmeye Koşut Olarak Sözbirim ve Terim Üretimi. Dilbilim. Cilt 1 sayı. 21. İstanbul: İstanbul Üniversitesi Edebiyat Fakültesi Dergisi. ss. 29-42.

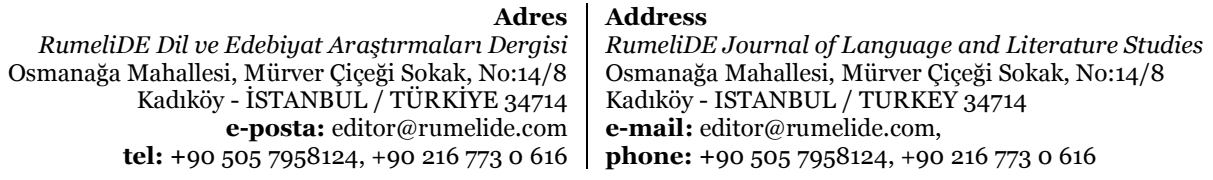

RumeliDE Dil ve Edebiyat Araştırmaları Dergisi Mürver Çiçegi Sokak, e-posta: editor@rumelide.com tel: +90 505 7958124, +90 2167730616 
Social sciences translations as a category of translation: characteristics, translation facts and professional proficiencies / L. Özcan (pp. 1052-1066)

Öztürk Kasar, S. (2010). ““Sosyal Bilimlerde Çeviri / Aktarılabilirlik ve Kültürlerüstü İletişim” Konulu Uluslararası Paris Kolokyumunun Düşündürdükleri”. Dilbilim, (24), 1-8. İstanbul Üniversitesi Edebiyat Fakültesi Dergisi. İstanbul.

Öztürk Kasar, S. (2015). Türk Göstergebiliminde Öncü Bir Yapıt: Anlatı Yerlemleri. Söylem, Söylen, Yazın, Tahsin Yücel’e Armağan. Ed. Nedret Öztokat Tanyolaç. İstanbul: Can Yayınları, 59-69.

Öztürk Kasar, S. (2017). Algirdas Greimas'ın La Sémantique structurale Adlı Yapıtını Türkçeye Nasıl Çevirmeli?. Cogito Ü̉ç Aylık Düşünce Dergisi. (86). Odak: Algirdas Julien Greimas, Dönem: Bahar 2017. İstanbul: Yapı Kredi, 308-316.

Öztürk Kasar, S. ve Tuna, D. (2017). Sosyal Bilimler Alanında Terimcelerin Çevrilmesi Ve Türkçe Terim Üretimi. Turkish Studies International Periodical for the Languages, Literature and History of Turkish or Turkic (12/13), 415-436. DOI Number: http://dx.doi.org/10.7827/TurkishStudies.

Öztürk Kasar, S. (2018a). Comment traduire Sémantique structurale d'Algirdas Julien Greimas en turc?. Dilbilim, (1), 69-113.

Öztürk Kasar, S. (2018b). La traduction turque du Cours de linguistique générale de F. de Saussure par B. Vardar:une version exemplaire d'un maître-traducteur. Cahiers de l'ILSL , (1), 75-97.

Roux, J. P. (2016). Orta Asya Tarih ve Uygarlık. Çev. Lale Özcan. (1. Basım, 2001). İstanbul:Kabalcı.

Roux, J. P. (2014). Dinlerin Çarpışması. Çev. Lale Özcan. İstanbul:Kabalcı.

Roux, J. P. (2018). Babur, Büyük Moğolların Tarihi. Çev. Lale Özcan. (1. Basım, 2008). İstanbul:Kabalcı.

Roux, J. P. (2020). Türklerin Tarihi. Çev. Aykut Kazancıgil - Lale Özcan. (1. Basım, Kabalcı, 2007). İstanbul: Dergah.

Roux, J.P. (1999). Montagnes sacrées, Montagnes mythiques. Paris:Fayard.

Roux., J.P. (2005). Orta Asya'da Kutsal Bitki ve Hayvanlar. Çev. Aykut Kazancıgil - Lale Özcan. İstanbul:Kabalcı.

Sapiro, G. (2012). La circulation des sciences humaines et sociales en traduction : enjeux et obstacles à l'heure de la globalisation. Traduire. 5-15. 10.4000/traduire., (465). http://traduire.revues.org/465

Schögler, R. Y. (2017). Les fonctions de la traduction en sciences humaines et sociales. Parallèles, 29(2), 36-45. https://doi.org/10.17462/para.2017.02.03. Erişim tarihi: 3 Mart 2020.

\footnotetext{
Adres $\mid$ Address

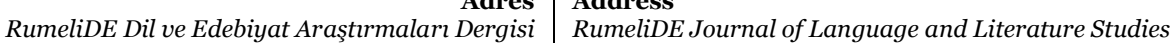

Osmanağa Mahallesi, Mürver Çiçeği Sokak, No:14/8 Osmanağa Mahallesi, Mürver Çiçeği Sokak, No:14/8

Kadıköy - İSTANBUL / TÜRKIYE 34714 Kadıköy - ISTANBUL / TURKEY 34714

e-posta: editor@rumelide.com e-mail: editor@rumelide.com

tel: +90 505 7958124, +90 2167730616 phone: +90 505 7958124, +90 2167730616
} 